\title{
Evaluation of anti-metastatic effect of chitosan nanoparticles on esophageal cancer-associated fibroblasts
}

\author{
Pravin D. Potdar, Aashutosh U. Shetti \\ Department of Molecular Medicine and Biology, Jaslok Hospital and Research Centre, Mumbai 400026, India.
}

Correspondence to: Dr. Pravin D. Potdar, Department of Molecular Medicine and Biology, Jaslok Hospital and Research Centre, Mumbai 400026, India. E-mail: ppravin012@gmail.com

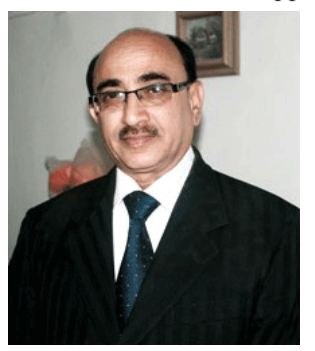

Dr. Pravin D. Potdar's present interest is to study molecular profiling of Circulating Tumor Cells (CTC), Circulating Tumor DNA, Cancer Associated Fibroblasts and Cancer Stem Cells involved in metastatic process of cancers, and to see how this process can be reverted back to normal by using innovated technologies which include nanotechnology and nanomedicine.

\begin{abstract}
Aim: Esophageal cancer is one of the major types of cancers, causing death of approximately $5 \%$ of all cancer deaths. This is due, in large part, to both relatively ineffectual and unavailable treatment. In order to develop an effective treatment strategy against esophageal cancer, it is important to target metastatic genes. In the present study, we have used a cancer-associated fibroblast (CAF) cell line derived from culturing peripheral blood mononuclear cells from a metastatic esophageal cancer patient to see whether chitosan nanoparticles ( $\mathrm{Ch}-\mathrm{Np}$ ) treatment can modulate the metastatic phenotype of CAF cells by using various cellular and molecular markers. Methods: A CAF cell line was developed from peripheral blood mononuclear cells (PBMC) from a metastatic esophageal cancer patient. The cells were treated with $100 \mu \mathrm{g} / \mathrm{mL}$ of chitosan nanoparticle in vitro for the morphological and oncogenic characteristic studies, along with the expression of various genes involved in process of tumor development and metastasis. Techniques such as Light and Phase Contrast Microscopy, cell growth rate, Scratch metastatic assay, and molecular profiling were carried out to see changes in CAF cells before and after Ch-Np treatment. Results: It was observed that CAF cells grew in monolayer and had a doubling time of $25 \pm 0.38 \mathrm{~h}$. Morphologically, the cells had a fibroblastic appearance. After treatment with $100 \mu \mathrm{g} / \mathrm{mL}$ of Ch-Np in vitro, there was an increased doubling time to $30 \pm 0.83 \mathrm{~h}$. Similarly, Scratch Assay showed an inhibition in the metastatic property of these cells. These findings were confirmed with gene expression studies. It was also observed that there was complete down-regulation of metastatic genes MMP1 and MMP9 and chemokines such as CXCR-4, CXCR-7, CCR-5, and SDF-1, indicating that Ch-Np inhibited the metastatic characteristic of CAF cells. Conclusion: This study has shown that there was an inhibition of metastatic properties of CAF cells after treatment with Ch-Np, suggesting that Ch-Np can be a delivery system used for targeting cancer cells for treatment of esophageal cancer.
\end{abstract}

Key words: Cancer-associated fibroblast; molecular markers; metastasis; chitosan nanoparticle; anti-metastatic; metastatic genes

\section{INTRODUCTION}

The tumor microenvironment plays a crucial role in development and progression of cancers. The microenvironment is mainly comprised of specialized stroma cells known as fibroblasts, also called cancerassociated fibroblast (CAF) or myofibriloblast. CAFs secrete various tumor promoting factors as well as angiogenic factors which accelerates tumor growth.

\begin{tabular}{|l|l|}
\hline \multicolumn{3}{|c|}{ Access this article online } \\
\hline Quick Response Code: & Website: \\
& http://www.jcmtjournal.com \\
\cline { 2 - 3 } & \\
\hline
\end{tabular}

Tumor Growth Factor $\beta$ (TGF- $\beta$ ) and Hepatocyte Growth Factor (HGF) are the mediators released by CAFs. These cause increased cell proliferation, more angiogenesis, and reduced apoptosis. ${ }^{[1]}$ CAFs have been found to play an important role in a variety of cancers, including breast, pancreatic, prostatic, and esophageal cancers. ${ }^{[2,3]}$

This is an open access article distributed under the terms of the Creative Commons Attribution-NonCommercial-ShareAlike 3.0 License, which allows others to remix, tweak, and build upon the work non-commercially, as long as the author is credited and the new creations are licensed under the identical terms.

For reprints contact: service@oaepublish.com

How to cite this article: Potdar PD, Shetti AU. Evaluation of antimetastatic effect of chitosan nanoparticles on esophageal cancer associated fibroblasts. J Cancer Metasta Treat 2016;2:259-67.

Received: 17-05-2016; Accepted: 06-07-2016. 
Esophageal cancer is an aggressive cancer, affecting 450,000 patients. In esophageal squamous cell carcinoma (ESCC) expression of HGF and fibroblast growth factor (FGF) in CAFs has been found to be related to tumor cell proliferation. ${ }^{[4]} \mathrm{CAF}$-derived wnt2, an important signaling molecule, was able to enhance a process called epithelial mesenchymal transition (EMT). This EMT involves loss of intracellular adhesion and polarity by tumor cells of epithelial origin. These cells can be transformed into mesenchymal cells with the capability of migration and invasion. ${ }^{[5]}$ Protein levels of CAF are also related to a poor prognosis of patients with esophageal cancer. Also, proteins such as $\alpha$ smooth muscle actin, CD-10, and periostin have been found to be related to the poor patient survival. ${ }^{[3]}$ Thus, it is evident that CAFs are important to tumor cells in esophageal cancer since they are associated with invasion, migration, and a poor prognosis. Many drug trials are carried out in order to develop a successful treatment strategy against esophageal cancer, but the role of CAF has been neglected. Hence, it is essential to attempt to target their CAF cells in order to prevent tumor progression.

In current cancer research nanoparticles are replacing traditional chemotherapeutic drugs because of their specificity, small size, and permeability into cells. Nanoparticles made up of biodegradable material such as chitosan have appeal since they are cheaper, do not involve toxic chemicals in their preparation, and have low cell cytotoxicity ${ }^{[6]}$ The chitosan nanoparticle has shown therapeutic significance in various cancers, including breast, gastric, and oral cancers. Chitosan nanoparticles have not been explored in esophageal cancer and their effect on CAFs has not yet studied. The current project was designed to understand the effects of chitosan nanoparticle on human peripheral blood-derived CAF by performing gene expression studies. We have attempted to demonstrate that chitosan nanoparticles alter expressions of genes involved in esophageal tumors and have found that these nanoparticles effectively reduced the metastasis of CAF cells. These results suggest that using chitosan nanoparticles targeting esophageal CAFs could be a potential therapeutic strategy against esophageal cancers.

\section{METHODS}

\section{Materials}

Low Molecular weight Chitosan ( $\geq 75 \%$ deacetylation), sodium Tri-polyphosphate (sTPP), Acetic Acid, 1N $\mathrm{NaOH}, \mathrm{D} / \mathrm{W}$, Low-glucose Dulbecco's Modified Eagle Medium (DMEM), Fetal Bovine Serum (FBS), Penicillin Streptomycin (PenStrep), L-Glutamine, Vitamin C, Phosphate Buffer Saline (PBS), Trypsin EDTA, TRIZOL reagent, cDNA Preparation kit (Applied Biosystem, USA), Agarose, Primers for Actin, Keratin18, Vimentin, VEGF, MMP1, MMP9, E-cadherin, CXCR-4, CXCR-7, CCR5, Sdf1 $\alpha$, Oct4, Nanog, SOX-2 were purchased from Sigma Chemicals, USA.

\section{Development and maintenance of esophageal CAF}

Peripheral blood from an esophageal squamous cell carcinoma (ESCC) patient was taken for extraction of CAF. Ficol-gradient was performed and separated cells cultured in RPMI supplemented with $10 \%$ FBS, Penstrep, and glutamate. After $24 \mathrm{~h}$ of culture the media were replaced with complete DMEM supplemented with $10 \%$ FBS, $1 \%$ Penstrep, $0.2 \%$ Glutamate, and Vit C. CAFs were seen after about 34 days of culturing. The cells were confluent within a week, then stored in $-80^{\circ} \mathrm{C}$ while some were maintained in culture. These cells were labeled as esophageal CAF. Frozen cells were revived and cultured in growth medium at passage number 31. Culture dishes were incubated at $37^{\circ} \mathrm{C}$ with $5 \% \mathrm{CO}_{2}$ and the media removed on alternate days, followed by washing of cells with PBS and supplementing with new media. After reaching confluency cells were trypsinized with $1 \%$ trypsin and transferred into fresh flask for expansion.

\section{Staining of CAF cell line (Giemsa, Alizarin Red, and Oil Red staining)}

Culture plates were washed with PBS, fixed with methanol $(50 \%)$, and incubated for $30 \mathrm{~min}$ at $4^{\circ} \mathrm{C}$. The plates were then washed with $\mathrm{D} / \mathrm{W}$ to remove the methanol. Fixed and washed plates of CAF were stained with Giemsa stain. Alizarin Red staining was required for the methanol-fixed cells, which were stained with $2 \%$ Alizarin stain (pH 4.2) for $30 \mathrm{~min}$. After oil red staining, the fixed and washed cells were incubated with $60 \%$ isopropanol for $5 \mathrm{~min}$. This was followed by removing the isopropanol and then staining with the $0.3 \%$ oil red for $5 \mathrm{~min}$. After staining the plates were washed with $\mathrm{D} / \mathrm{W}$ to remove excess stain.

\section{Phase contrast microscopy}

Inverted Phase contrast Microscope (Carl Zeiss Co.) was used for studying morphology of the cultured cells. The microscope was attached to the computer having TS View software for observing and capturing the images. The cells were monitored regularly with the use of phase contrast microscope and images captured.

\section{Chitosan nanoparticle (Ch-Np) preparation}

$\mathrm{Ch}-\mathrm{Np}$ was prepared using the ionic gelation method. Low molecular weight chitosan was dissolved in $1 \%$ acetic acid under constant stirring conditions. Zero point one percent sTPP prepared in $\mathrm{D} / \mathrm{W}$ was added in the chitosan solution, drop by drop, under constant stirring. A solution change from clear to turbid was taken as confirmation for nanoparticle formation. $\mathrm{pH}$ of the chitosan solution was adjusted to 7 using $1 \mathrm{~N}$ $\mathrm{NaOH}$. Formed nanoparticles suspended in the solution were separated by centrifuging at $2000 \mathrm{~g}$ for $3 \mathrm{~min}$. The supernatant was discarded and the nanoparticles were washed with DMEM and again centrifuged in order to remove any chemical residue. The nanoparticles were then suspended in the media for later use. 
Growth curve for control vs. treated CAF

Cells were plated at a density of $5 \times 10^{4}$ per well in a 6 well plate and fed with the DMEM medium. The cells were collected from each well at different time intervals, i.e., $24 \mathrm{~h}, 48 \mathrm{~h}, 72 \mathrm{~h}$, and $96 \mathrm{~h}$. For each time point the cells were washed with $1 \times$ PBS and trypsinized. The trypsinized cells were mixed with equal amount of Erythrocin B. The cell count was taken by using Neubauer hemocytometer. The cell growth rate was carried out for control and $100 \mu \mathrm{g}$ treated $\mathrm{Ch}-\mathrm{Np}$. The experiment was repeated three times and average growth and Standard Deviation were calculated for each time point.

\section{Cellular morphology of CAF cells}

CAF cell morphology was observed before and after treatment with Ch-Np. Sixty-five millimeter petri dishes were seeded with $5 \times 10^{4}$ cells per plate. Two plates were taken, one as untreated control whereas another dish was treated with $100 \mu \mathrm{g} / \mathrm{mL}$ Ch-Np. Cell morphology was observed under phase contrast microscopy for after $24 \mathrm{~h}$, $48 \mathrm{~h}$, and $72 \mathrm{~h}$ of treatment and compared to control cells.

\section{Molecular marker analysis}

Two $65 \mathrm{~mm}$ petri dishes were seeded with $20 \times 10^{4}$ cells per plate. The cells were then washed with PBS and fed with new DMEM daily. After 2 days one plate was treated with $100 \mathrm{ug} / \mathrm{mL} \mathrm{Ch}-\mathrm{Np}$. After $24 \mathrm{~h}$ of treatment the cells were washed with PBS and RNA extraction from cells was carried out using TRIZOL method (Invitrigen). cDNA was prepared from extracted RNA by using cDNA Reverse transcriptase kit. Gene expression studies were performed using PCR. The PCR mix consisted of ammonium sulphate buffer including $1.5 \mathrm{~mm} \mathrm{MgCl}, 200 \mu \mathrm{m}$ of each of the dNTPs, $200 \mathrm{ng} / \mu \mathrm{L}$ each primer, $1 \mathrm{U}$ Taq Polymerase, and $5 \mu \mathrm{L}$ cDNA. Pluripotency markers (Oct-4, Nanog, SOX2), differentiating markers (Keratin 18, Vimentin, E-Cadherin, VEGF), chemokine and cytokine (CXCR4, CXCR-7, CCR5 and Sdf-1 $\alpha$ ), and metastatic markers (MMP1, MMP9) were used. Primers and annealing temperatures used for these genes are mentioned in Table 1. Initial denaturation was carried out at $95^{\circ} \mathrm{C}$ followed by denaturation at $94^{\circ} \mathrm{C}$; annealing (specified in Table 1), extension at $72^{\circ} \mathrm{C}$ and final extension at $72^{\circ} \mathrm{C}$ for $7 \mathrm{~min}$. Forty cycles were run for each PCR followed by gel loading and observation under UV-illuminator and photographed.

\section{Scratch assay for evaluation of CAF migration}

Two $65 \mathrm{~mm}$ plates were initially seeded with $5 \times 10^{4}$ cells per plate. The cells were then allowed to reach confluency. After reaching confluency, both dishes were scratched with the help of a sterile scalpel. Care was taken to scratch equal areas in both culture plates. This caused a loss of cells on the scratched area. The scratched control plate was kept as it is whereas other the scratched plate was treated with $100 \mu \mathrm{g} / \mathrm{mL} \mathrm{Ch}-\mathrm{Np}$ and incubated at $37^{\circ} \mathrm{C}$ at $5 \% \mathrm{CO}_{2}$. The scratched area was observed under the phase contrast microscope after $24 \mathrm{~h}, 48 \mathrm{~h}$, and $72 \mathrm{~h}$ of treatment and photographed for cell migration. This experiment was

Table 1: Primer sequence, annealing temperature and size of band for molecular markers

\begin{tabular}{|c|c|c|c|}
\hline Name & Primer & Annealing $\left({ }^{\circ} \mathrm{C}\right)$ & Size (bp) \\
\hline \multirow{2}{*}{ Actin } & GACTACCTCATGAAGATC & \multirow{2}{*}{55} & \multirow{2}{*}{417} \\
\hline & Downstream GATCCACATCTGCTGGAA & & \\
\hline \multirow{2}{*}{ Oct4 } & Upstream GAGCAAAACCCGGAGGAGT & \multirow{2}{*}{55} & \multirow{2}{*}{310} \\
\hline & Downstream TTCTCTTTCGGGCCTGCAC & & \\
\hline \multirow{2}{*}{ Nanog } & Upstream GCTTGCCTTGCTTTGAAGCA & \multirow{2}{*}{55} & \multirow{2}{*}{256} \\
\hline & $\begin{array}{ll}\text { Downstream } & \text { TTCTTGACCGGGACCTTGTC } \\
\text { Upstream } & \text { GCCGAGTGGAAACTTTTGTC }\end{array}$ & & \\
\hline $\mathrm{SOX} 2$ & Downstream GTTCATGTGCGCGTAACTGT & 57 & 264 \\
\hline \multirow{2}{*}{ Keratin } & Upstream GAGATCGAGGCTCTCAAGGA & \multirow{2}{*}{55} & \multirow{2}{*}{357} \\
\hline & Downstream CAAGCTGGCCTTCAGATTTC & & \\
\hline \multirow{2}{*}{ Vimentin } & Upstream TTCAGAGAGAGGAAGCCGAAAAC & \multirow{2}{*}{62} & \multirow{2}{*}{426} \\
\hline & $\begin{array}{ll}\text { Downstream } & \text { TTTAAGGGCATCCACTTCACAG } \\
\text { Upstream } & \text { GAAGTGGTGAAGTTCATGGATGTC }\end{array}$ & & \\
\hline VEGF & Downstream CGATCGTTCTGTATCAGTCTTTCC & 62 & 422 \\
\hline \multirow{2}{*}{ E-Cadherin } & Upstream $\quad$ TGCTCTTGCTGTTTCTTCGG & \multirow{2}{*}{60} & \multirow{2}{*}{422} \\
\hline & $\begin{array}{ll}\text { Downstream } & \text { TGCCCCATTCGTTCAAGTAG } \\
\text { Upstream } & \text { CTGAAGGTGATGAAGCAGCC }\end{array}$ & & \\
\hline MMP1 & Downstream AGTCCAAGAGAATGGCCGAG & 55 & 427 \\
\hline \multirow{2}{*}{ MMP9 } & Upstream CGCAGACATCGTCATCCAGT & \multirow{2}{*}{64} & \multirow{2}{*}{405} \\
\hline & $\begin{array}{ll}\text { Downstream } & \text { GGATTGGCCTTGGAAGATGA } \\
\text { Upstream } & \text { GGACCTGTGGCCAAGTTCTTAGTT }\end{array}$ & & \\
\hline CXCR-4 & Downstream ACTGTAGGTGCTGAAATCAACCCA & 60 & 273 \\
\hline \multirow{2}{*}{ CXCR-7 } & Upstream $\quad$ TGGGTGGTCAGTCTTCGT & \multirow{2}{*}{60} & 293 \\
\hline & $\begin{array}{ll}\text { Downstream } & \text { CCGGCAGTAGGTCTCAT } \\
\text { Upstream } & \text { CTTCATCATCCTCCTGACAATCG }\end{array}$ & & 200 \\
\hline C(R-) & Downstream GACCAGCCCCAAGTTGACTATC & 60 & 261 \\
\hline Sdf- $1 \alpha$ & Upstream TGATCGTCTGACTGGTGTTA & 60 & 188 \\
\hline & Downstream CTTAGGGGATTTGGAAGTTT & & \\
\hline
\end{tabular}



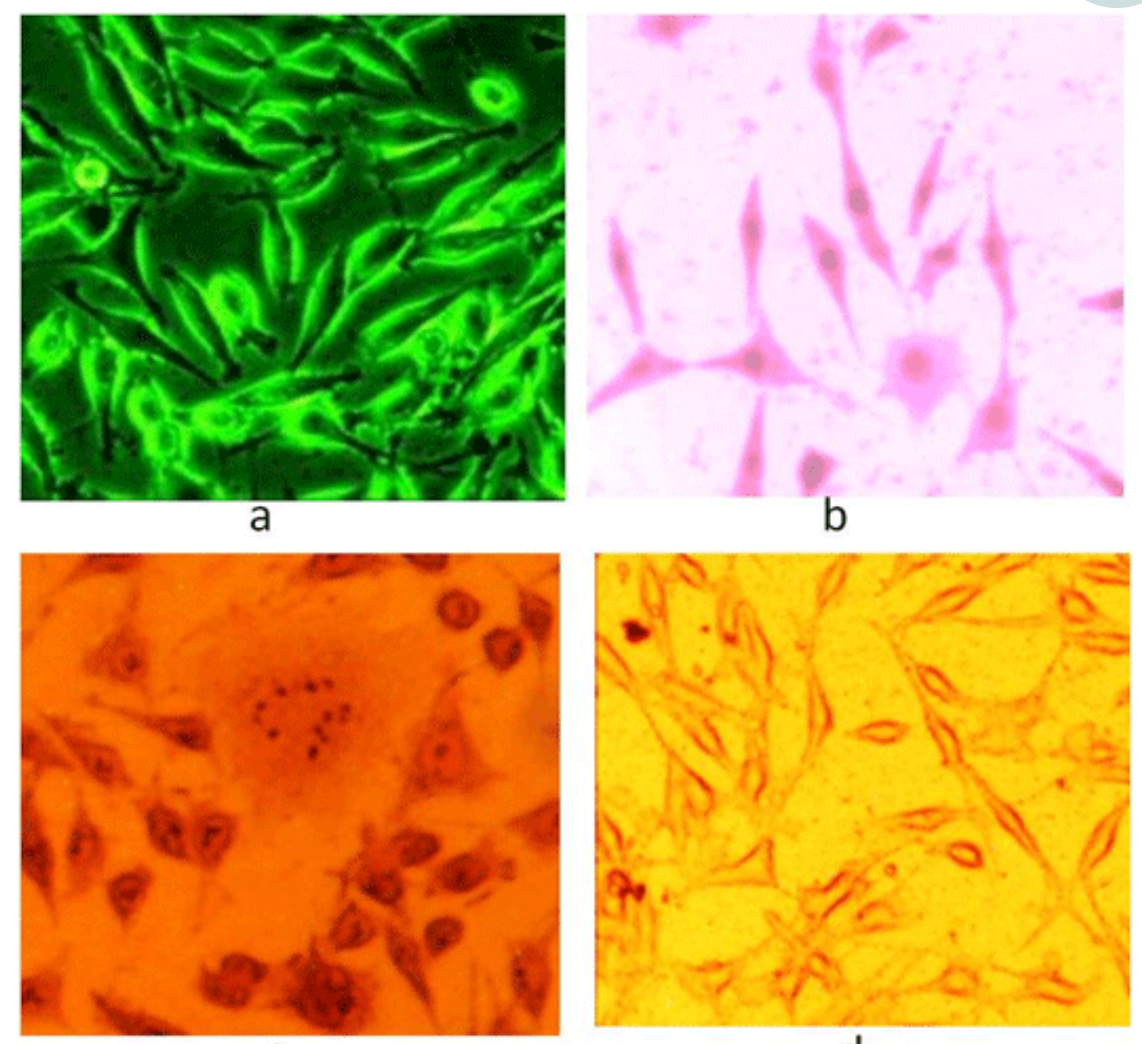

C

d

Figure 1: (a) Phase contrast microscope image of CAF; (b) giemsa staining; (c) alizarin staining; (d) oil red staining of CAF. CAF: cancer associated fibroblast

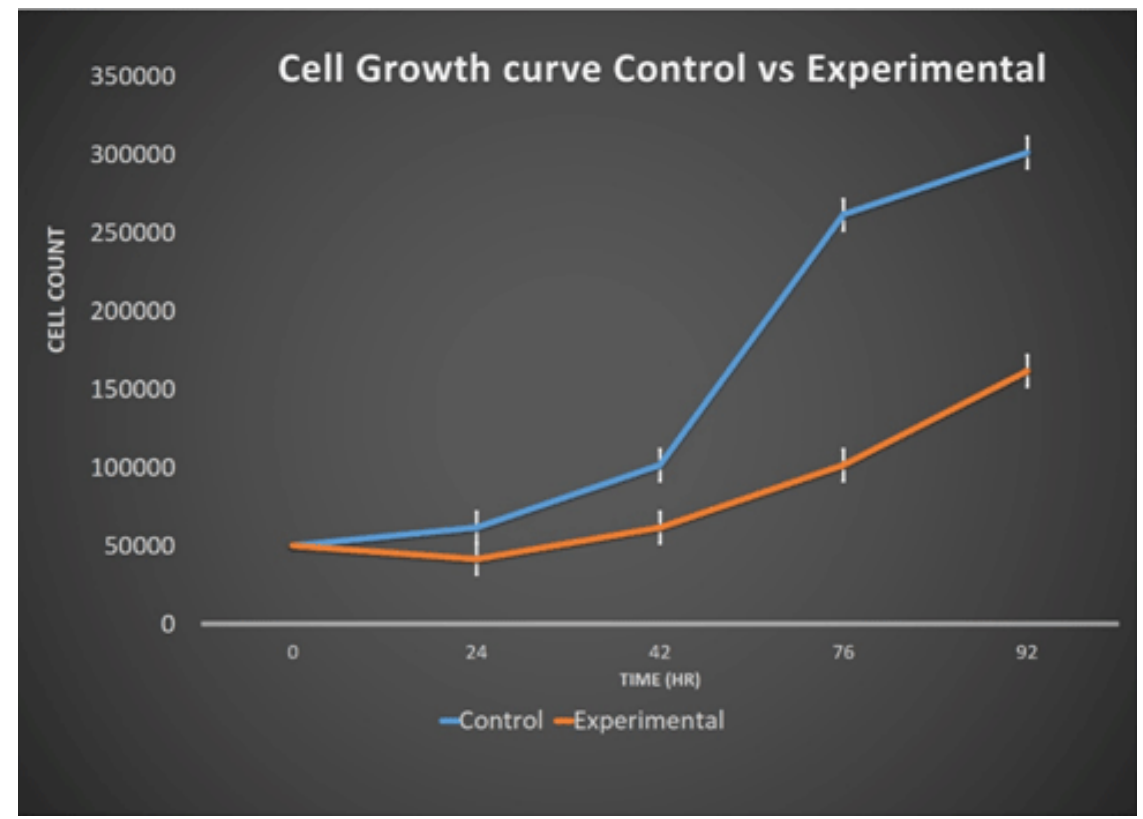

Figure 2: Cell growth curve for control untreated cells vs. Ch-Np-treated cells effect of Ch-Np on alignment of CAF. CAF: cancer associated fibroblast

repeated twice with the same number of cells and using same scalpel for making the scratch.

\section{RESULTS}

\section{Morphological characterization of CAF cells by phase contrast microscopy}

Esophageal CAF showed fibroblast-like appearance, having extended cellular filaments as shown in Figure 1a. Giemsa Stain stained the nucleus of CAF, as shown in Figure 1b, making the nucleus completely visible and showing clear cytoplasm. Calcium granules within CAF cytoplasm of were stained by Alizarin Stain as shown in Figure 1c. Oil Red staining did not impart any color on the cells as shown in Figure 1d, indicating that there were no adipocytes. 


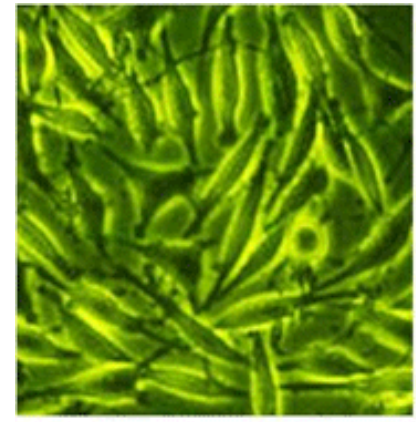

a

d

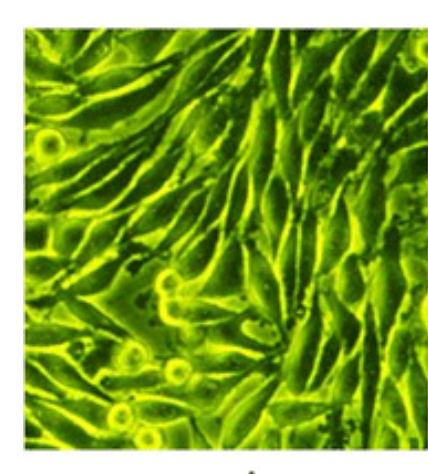

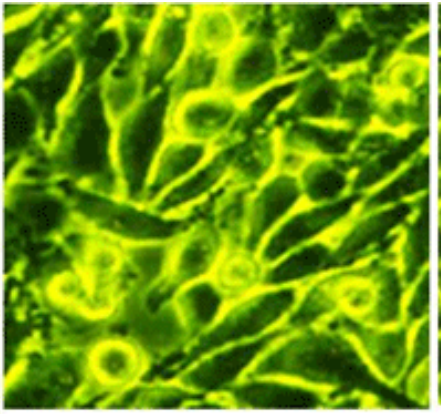

b

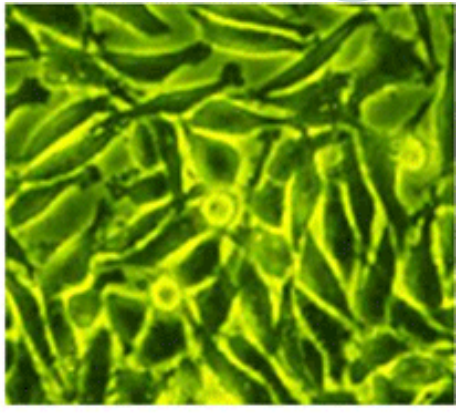

C

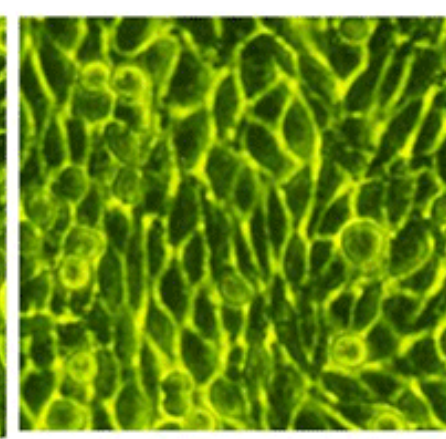

e

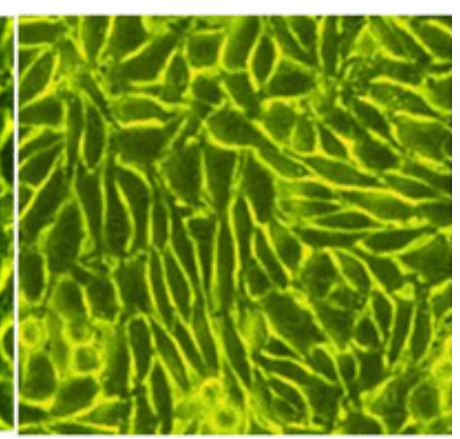

f

Figure 3: (a) Randomized alignment of control cells after $24 \mathrm{~h}$; (b) randomized alignment of control cells after 48 h; (c) randomized alignment of control cells after $72 \mathrm{~h}$; parallel alignment of Ch-Np-treated cells [(d), (e), (f)]

\section{Growth curve for control vs. treated CAF}

Growth curve for untreated CAF showed a gradual increase in the number of cells during 0-24 and 24$48 \mathrm{~h}$. After $48 \mathrm{hr}$ the number of cells almost doubled. However, the 72-96 h time duration did not show a doubling of cells. This experiment was repeated three times and overall doubling time for untreated cells was $25 \pm 0.38 \mathrm{~h}$ [Figure 2]. In the case of treated cells, during first $24 \mathrm{~h}$, the cell count was less than the initially seeded cells. Then, cells showed a gradual increase in number. Importantly, the doubling rate of treated cells was increased because the number of cells after $92 \mathrm{~h}$ of culturing in the treated plate was less than that of control cells, as shown in Figure 2. This experiment was repeated three times and the overall doubling time for treated cells was $30 \pm 0.83 \mathrm{~h}$ [Figure 2].

\section{Cellular morphology of CAF cells}

Phase-contrast morphology of untreated and Ch-Nptreated esophageal CAF was observed at 24, 48 and $72 \mathrm{~h}$. Untreated CAF cells showed random growth and cells were overlapping with each other, as shown in Figure 3a, 3b, and 3c, whereas in the case of ChNp-treated plates, the cells exhibited monolayers with equal gaps and looked parallel to each other, as shown in Figure 3d, 3e, and 3f. These cells did not overlap with each other as was observed in the control CAF cells. This seems to indicate that they changed their malignant phenotype towards a normal phenotype by Ch-Np treatment.

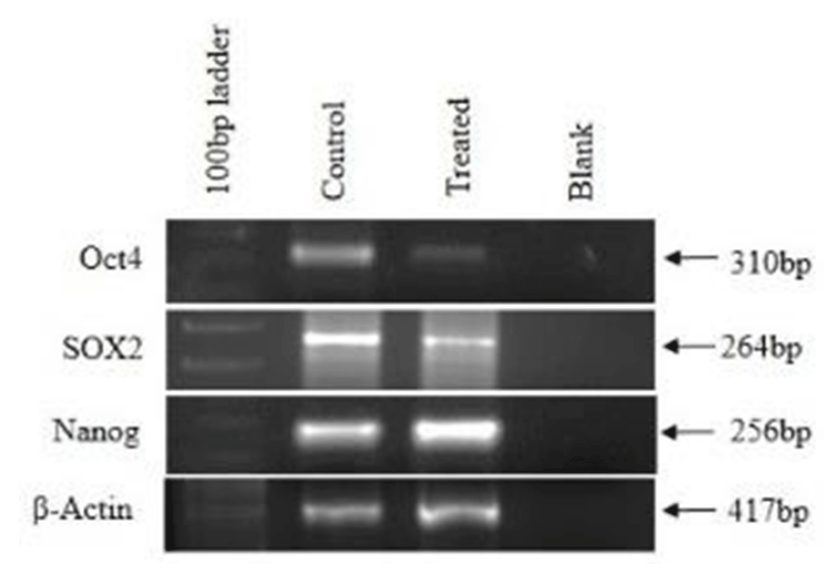

Figure 4: Expression of pluripotency markers in control and treated cells

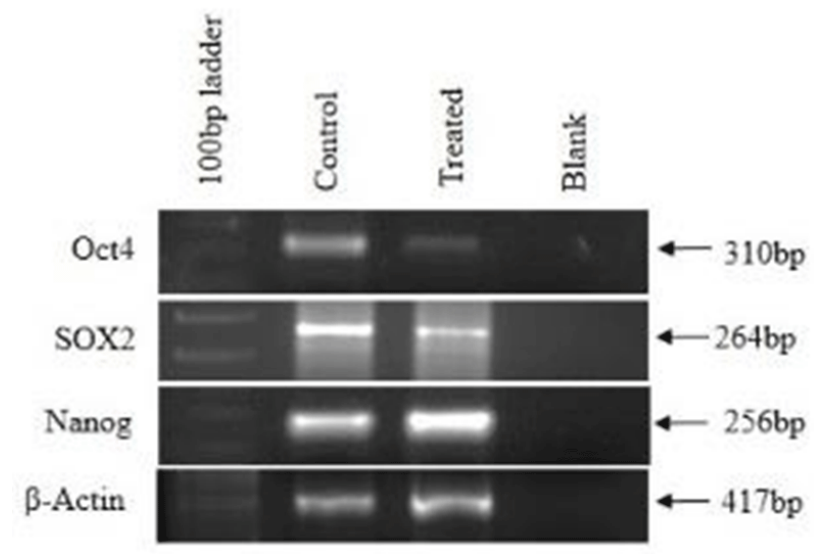

Figure 5: Expression of differentiating markers in control and treated cells 


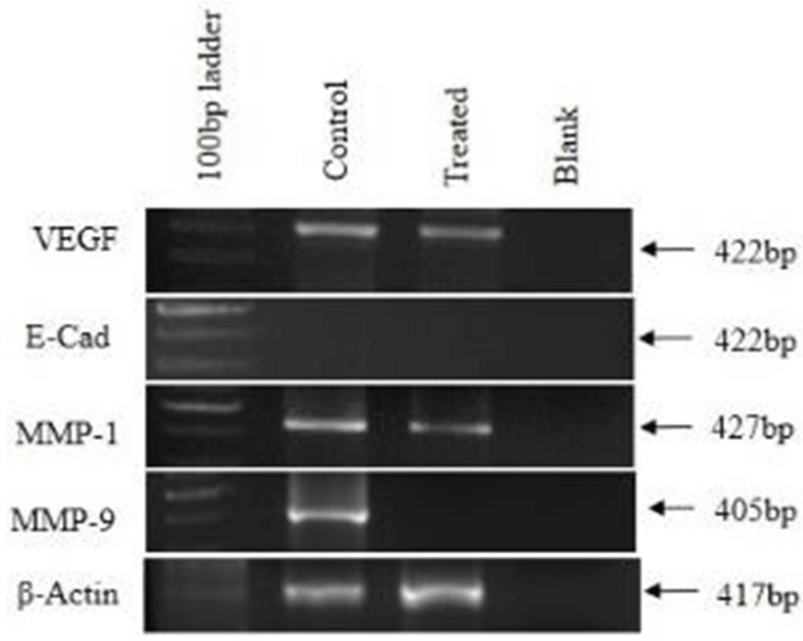

Figure 6: Expression of metastatic markers in control and treated cells

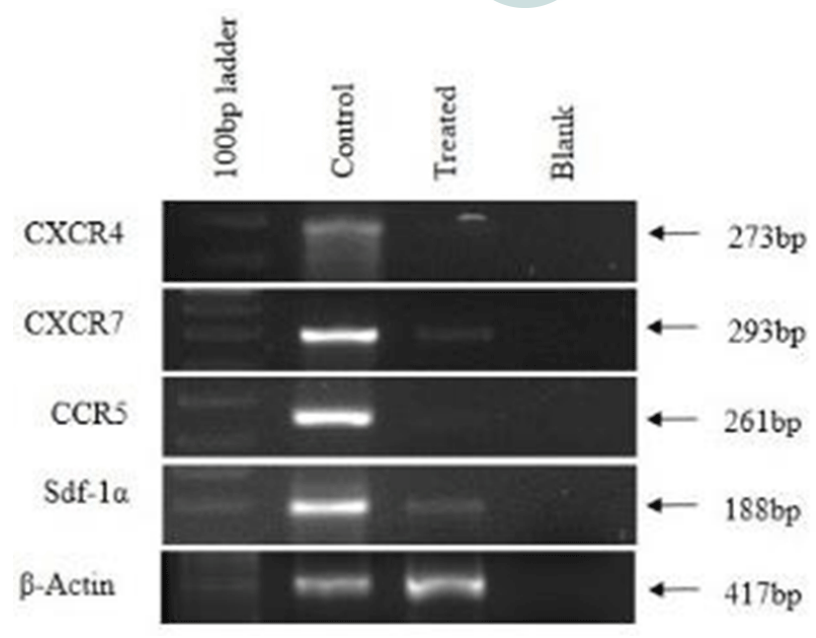

Figure 7: Expression of chemokine and chemokine receptors

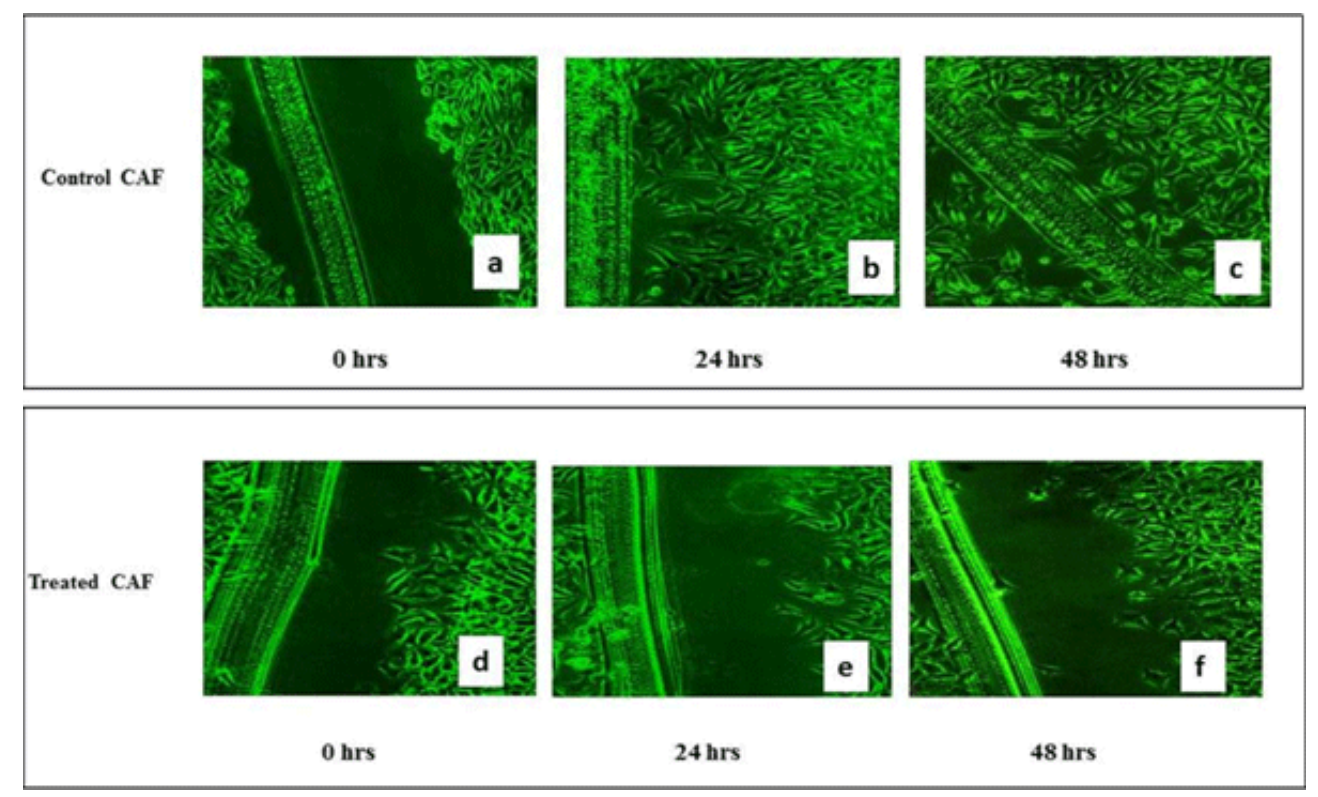

Figure 8: (a) Scratched Assay performed on control CAF after $24 \mathrm{~h}$; (b) Scratched Assay performed on control CAF after 48 h; (c) Scratched Assay performed on control CAF after $72 \mathrm{~h}$; (d) Ch-Np-treated cells after $24 \mathrm{~h}$; (e) Ch-Np-treated cells after 48 h; (f) Ch-Np-treated cells after $72 \mathrm{~h}$

\section{Molecular marker studies}

This study was undertaken to evaluate mRNA expression of pluripotency, differentiation, metastatic spread, and chemokine markers in CAF cells before and after treatment with $\mathrm{Ch}-\mathrm{Np}$ by using specific primers as described in Table 1.

\section{Pluripotency markers in CAF and Ch-Np- treated CAF}

Pluripotency of cells is defined as properties of stem cells which allow cells to proliferate indefinitely. Oct4, Nanog, and Sox 2 are known as such markers. These markers were studied in untreated and treated CAF cells. It was shown that these CAF cells normally expressed Oct4, Nanog, and Sox2, indicating their proliferative activity as transformed cells. However, in the Ch-Np treated cells, Oct4 and Sox 2 genes were down regulated and Nanog remained unchanged, as shown in Figure 4.

\section{Differentiating markers in CAF and Ch-Np- treated CAF \\ Keratin18 and Vimentin were the two differentiating markers studied in CAF- and Ch-Np-treated cells. Figure 5 shows prominent expression of Keratin 18 and Vimentin. However, both these genes were down-regulated in $\mathrm{Ch}$ - Np-treated cells.}

\section{Metastatic markers in CAF and Ch-Np-treated CAF}

VEGF, MMP1, and MMP9 were studied as metastatic genes in CAF and Ch-Np-treated CAF. There was slight down-regulation of VEGF and MMP1 genes in Ch-Nptreated CAF. However, complete down-regulation of MMP9 was observed in Ch-Np-treated CAF [Figure 6]. Also studied was E-Cadherin, an adhesive molecule and actively involved in the EMT (define EMT) process. It was observed that there was complete-down regulation of E-Cadherin in CAF as well as in Ch-Np-treated CAF, 
as shown in Figure 6.

\section{Chemokines in CAF- and Ch-Np-treated CAF}

CXCR4, CXCR7, and CCR5 are chemokine receptors mainly involved in the process of metastasis where Sdf$1 \alpha$ is a ligand to CXCR4. Their expressions were studied in $\mathrm{CAF}$ and $\mathrm{Ch}-\mathrm{Np}$-treated CAF. Figure 7 shows complete down-regulation of CXCR4 and CCR5 in Ch-Np treated CAF cells. Also, there was slight expression observed in CXCR7 and Sdf- $1 \alpha$ in Ch-Np treated CAF cells as compared to control CAF cells, as shown in Figure 7. Control CAF cells expressed all these genes normally [Figure 7].

\section{Evaluation of metastatic potency of CAF cells by scratch assay}

Scratch assay is mainly useful to evaluate migration potencies of metastatic cells. As CAFs were isolated from a metastatic patient, the scratch assay was used to study the metastatic potency in control CAF cells and Ch-Nptreated CAF.

This effect was studied at two time points, i.e, 24 and $48 \mathrm{~h}$ after Ch-Np treatment, as shown in Figure 8. It was observed that there was good migration of these cells in a scratch area in control CAF dishes, even at $24 \mathrm{~h}$. In $48 \mathrm{~h}$ many cells were seen in scratch area in control CAF [Figure 8a, 8b, and 8c], whereas CAF cells treated with Ch-Np showed few cells migration after $24 \mathrm{~h}$ and $48 \mathrm{~h}$, as shown in Figure 8d, 8e, and $8 \mathrm{f}$. These observations indicated that $\mathrm{Ch}-\mathrm{Np}$ treatment affects cell motility after $48 \mathrm{~h}$ of treatment.

\section{DISCUSSION}

CAFs are some of the most important stromal cells involved in tumor initiation, progression, and its metastasis in ESCC. ${ }^{[7]}$ It is important to attempt to target these cells along with their cancer cells when developing a drug against the cancer. Recent trends in drug development involve the use of nanoparticles which are efficient in drug delivery. Chitosan nanoparticle is one such nanoparticle which is being explored in various cancers and other diseases. ${ }^{[8]}$ Our study focused on evaluating the anti-metastatic effect of $\mathrm{Ch}-\mathrm{Np}$ on CAF isolated from the peripheral blood of a patient with metastatic esophageal cancer.

CAFs have shown extensive growth proliferation and multiply at a doubling time of $25 \pm 0.38 \mathrm{~h}$. However Ch-Np-treated cells have inhibited the growth of these cells, indicating an inhibitory effect of Ch-Np on CAFs. Studies have shown that Ch-Np inhibited the growth of breast cancer cells in vitro. ${ }^{[9]}$ Similarly, another group found $^{[8]}$ that $\mathrm{Ch}-\mathrm{Np}$ effectively inhibited proliferation of a human gastric carcinoma cell line, indicating its potential beneficial activity against human gastric cancer. The present study also indicated the potential use of Ch-Np for inhibition of growth of metastatic esophageal cancer.

Cancer cells are resistant to contact inhibition, a common phenomenon in normal cells. ${ }^{[10]}$ In current study CAF cells showed random overlapping cell growth in the control plates, whereas in $\mathrm{Ch}-\mathrm{Np}$-treated cells they were aligned in parallel fashion and showed clear cut monolayer cells, as if they were having normal phenotypic growth. The results further showed that these cells seem to have better contact inhibition than control CAF cells, which had metastatic potential. ${ }^{[1]}$ This might be the reason for the random growth of CAF since they were isolated from metastatic PBMC cells of the esophageal cancer patient. These phenotypic changes were confirmed by molecular markers studied in this project.

Several studies have shown that Oct4, Nanog, and Sox2 are excellent pluripotency markers in cancer cells. ${ }^{[12,13]}$ In the present study mRNA expression of Oct4, Nanog, and Sox 2 in control CAF and Ch-Np-treated CAF were studied. Prominent expression of this pluripotency marker in control CAF was found. According to one study, ${ }^{[14]}$ Oct4 played an important role in promoting carcinogenesis and also in preventing cancer cells from undergoing apoptosis. Another group ${ }^{[15]}$ found that expression of Oct4 and Sox2 was altered in ESCC and together they impart a poor prognosis in the disease. In the present study down-regulation of Oct-4 and Sox 2 in CAF after Ch-Np treatment was observed. Thus, clinical inhibition in expression of these genes may give hope a better outcome in ESCC.

In order to understand the characteristics of CAFs, the expression of keratin18, an epithelial marker in cancer cells, was studied. Keratin 18 is currently mainly studied to understand prognosis in cancer patients. ${ }^{[16]}$ Recently it was ${ }^{[17]}$ noticed that there was up-regulation of keratin 18 in breast cancer patients. This coincides with the observation in the current study where there was a higher expression of Keratin 18 in CAF cells. Furthermore, in the current study there was a complete down-regulation of keratin18 after treatment of Ch-Np, implying the acquisition of a normal cell phenotype and loss of tumor progression capability. Vimentin was also studied in the present study and its expression was noticed on CAFs. This is accordance with a previous study. ${ }^{[18]}$ Over-expression of Vimentin in cancer cells has been associated with increased invasion and metastasis in tumor. According to one study ${ }^{[19]}$ inhibition of vimentin expression reduced cancer cell migration. Downregulation in expression of vimentin was observed in the $\mathrm{Ch}-\mathrm{Np}$-treated $\mathrm{CAF}$, suggesting that $\mathrm{Ch}-\mathrm{Np}$ can reduce cell migration and, ultimately, metastasis. Metastasis is an important characteristic of cancers which is governed by genes such as VEGF, MMP1, MMP9, and E-Cadherin. MMP1 and MMP9 have been found to be associated with cancer cell metastasis in ESCC. ${ }^{[20]}$ Down-regulation in these two important genes, MMP1 and MMP9, observed 
in Ch-Np-treated cells, may thus reduce the metastatic ability of cancer cells.

As mentioned earlier, CAFs are derived from the tumor by the process of EMT, which involves loss of intracellular adhesion. The absence of E-cadherin in control CAFs supports the process of EMT and loss of intracellular adhesion. ${ }^{[5,21]}$ The other important molecular marker, VEGF, which plays a role of angiogenesis, was also not affected by $\mathrm{Ch}-\mathrm{Np}$ treatment. ${ }^{[22]}$ Hence, future studies have to be done with $\mathrm{Ch}-\mathrm{Np}$ on CAFs so as to target E-cadherin and VEGF. Tumor development involves a variety of chemokines which are secreted by cancer cells. CXCR4, CXCR7, CCR5, and Sdf-1 $\alpha$ are some such chemokines. Prominent expression of CXCR4 in esophageal cancer has been shown to have a poor long term prognosis and involvement in tumor spread. ${ }^{[23]}$ CXCR 4 and its ligand, Sdf- $1 \alpha$, were found to be involved in the metastasis of esophageal cancer in an in vivo model. ${ }^{[24]}$ The role of CXCR7 and CCR5 in esophageal cancer is poorly understood but in breast cancer they are involved in proliferation and metastasis. ${ }^{[25,26]}$ Hence, these chemokines serve as important metastatic genes in the case of esophageal cancer. Down-regulation was noticed in expression of CXCR4, CXCR7, CCR5, and Sdf- $1 \alpha$ in Ch-Np-treated CAF, implying anti-metastatic activity of Ch-Np. Further support to our hypothesis of anti-metastatic activity of Ch-Np was provided by the Scratch Assay in which treated CAFs did not spread in the scratched area, indicating loss of metastatic activity.

In conclusion, chitosan is a biopolymer which has been extensively studied for its ability to encapsulate the drug molecule within it. In our study we have shown anti-tumor and mainly anti-metastatic ability of Ch-Np on esophageal CAF. Decrease in the various genes by chitosan shows that it is a promising drug molecule in the treatment of metastatic cancer. Hence, chitosan should not be considered only as a carrier of drug molecules but should be considered as a drug itself. Also, in order to better treat ESCC, it is important to study the stromal cell fraction and its molecular mechanism so as to develop molecular targeted therapy. Encapsulation of an anticancer drug within Ch-Np could work as a dual stratagem against cancer, targeting both cancer and CAFs. Hence, future clinical and pharmacological studies with Ch-Np need to be done.

\section{Acknowledgments}

Authors wish to thank Management of Jaslok Hospital and Research Center for allowing us to carry out this work at their institute and for their constant support. We also thank Ms. Keerti Sen for her initial technical work on this project.

\section{Financial support and sponsorship} Nil.

\section{Conflicts of interest}

There are no conflicts of interest.

\section{REFERENCES}

1. Cheng N, Bhowmick NA, Chytil A, Gorksa AE, Brown KA, Muraoka R, Arteaga CL, Neilson EG, Hayward SW, Moses HL. Loss of TGF-beta type II receptor in fibroblasts promotes mammary carcinoma growth and invasion through upregulation of TGFalpha-, MSP- and HGF-mediated signaling networks. Oncogene 2005;24:5053-68.

2. Cirri P, Chiarugi P. Cancer-associated-fibroblasts and tumour cells: a diabolic liaison driving cancer progression. Cancer Metastasis Rev 2012;31:195-208

3. Ha SY, Yeo SY, Xuan YH, Kim SH. The prognostic significance of cancer-associated fibroblasts in esophageal squamous cell carcinoma. PLoS One 2014;9:e99955.

4. Saito S, Morishima K, Ui T, Hoshino H, Matsubara D, Ishikawa S, Aburatani H, Fukayama M, Hosoya Y, Sata N, Lefor AK, Yasuda Y, Niki T. The role of HGF/MET and FGF/FGFR in fibroblastderived growth stimulation and lapatinib-resistance of esophageal squamous cell carcinoma. BMC Cancer 2015;15:82.

5. Fu L, Zhang C, Zhang LY, Dong SS, Lu LH, Chen J, Dai Y, Li Y, Kong KL, Kwong DL, Guan XY. Wnt2 secreted by tumour fibroblasts promotes tumour progression in oesophageal cancer by activation of the Wnt/-catenin signalling pathway. Gut 2011;60:1635-43.

6. Nagpal K, Singh SK, Mishra DN. Chitosan nanoparticles: a promising system in novel drug delivery. Chem Pharm Bull 2010;58:1423-30

7. Bremnes RM, Dønnem T, Al-Saad S, Al-Shibli K, Andersen S, Sirera R, Camps C, Marinez I, Busund LT. The role of tumor stroma in cancer progression and prognosis: emphasis on carcinomaassociated fibroblasts and non-small cell lung cancer. J Thorac Oncol 2011;6:209-17.

8. Qi LF, Xu ZR, Li Y, Jiang X, Han XY. In vitro effects of chitosan nanoparticles on proliferation of human gastric carcinoma cell line MGC803 cells. World J Gastroenterol 2005;11:5136-41.

9. Zhang Yong-cheng, Wu Xiao-ying, Chen Xiao-lan. Inhibitory effect of chitosan nanoparticles-mediated HER-2 siRNA on migration of breast cancer cell line SK-BR-3. Chinese Journal of Breast Disease (Electronic Edition) 2011 May." [Online]. Available from: http:// en.cnki.com.cn/Article_en/CJFDTOTAL-ZHRD201105011.htm

10. Seluanov A, Hine C, Azpurua J, Feigenson M, Bozzella M, Mao Z, Catania KC, Gorbunova V. Hypersensitivity to contact inhibition provides a clue to cancer resistance of naked mole-rat. Proc Natl Acad Sci U S A 2009;106:19352-7.

11. Kraning-Rush CM, Reinhart-King CA. Controlling matrix stiffness and topography for the study of tumor cell migration. Cell Adh Migr 2012;6:274-9.

12. Potdar PD, D'Souza SB. Ascorbic acid induces in vitro proliferation of human subcutaneous adipose tissue derived mesenchymal stem cells with upregulation of embryonic stem cell pluripotency markers Oct4 and SOX 2. Hum Cell 2010;23:152-5.

13. Pravin Potdar, Sachin Chaugule. Establishment and molecular characterization of breast cancer mesenchymal stem cell line derived from human non-metastasis breast cancer tumor. Stem Cell Discov 2011;2:21-8.

14. Wang YD, Cai N, Wu XL, Cao HZ, Xie LL, Zheng PS. OCT4 promotes tumorigenesis and inhibits apoptosis of cervical cancer cells by miR-125b/BAK1 pathway. Cell Death Dis 2013;4:e760.

15. Wang Q, He W, Lu C, Wang Z, Wang J, Giercksky KE, Nesland JM, Suo Z. Oct3/4 and Sox 2 are significantly associated with an unfavorable clinical outcome in human esophageal squamous cell carcinoma. Anticancer Res 2009;29:1233-41.

16. Ha SA, Lee YS, Kim HK, Yoo J, Kim S, Gong GH, Lee YK, 
Kim JW. The prognostic potential of keratin 18 in breast cancer associated with tumor dedifferentiation, and the loss of estrogen and progesterone receptors. Cancer Biomark 2011;10:219-31.

17. Kabir NN, Rönnstrand L, Kazi JU. Keratin 19 expression correlates with poor prognosis in breast cancer. Mol Biol Rep 2014;41:7729-35.

18. Mishra PJ, Mishra PJ, Humeniuk R, Medina DJ, Alexe G, Mesirov JP, Ganesan S, Glod JW, Banerjee D. Carcinoma-associated fibroblast-like differentiation of human mesenchymal stem cells. Cancer Res 2008;68:4331-9.

19. McInroy L, Määttä A. Down-regulation of vimentin expression inhibits carcinoma cell migration and adhesion. Biochem Biophys Res Commun 2007;360:109-14.

20. Gu ZD, Li JY, Li M, Gu J, Shi XT, Ke Y, Chen KN. Matrix metalloproteinases expression correlates with survival in patients with esophageal squamous cell carcinoma. Am $J$ Gastroenterol 2005;100:1835-43.

21. van Roy F, Berx G. The cell-cell adhesion molecule E-cadherin. Cell Mol Life Sci 2008;65:3756-88.
22. Carmeliet P. VEGF as a key mediator of angiogenesis in cancer. Oncology 2005;69 Suppl 3:4-10.

23. Gockel I, Schimanski CC, Heinrich C, Wehler T, Frerichs K, Drescher D, von Langsdorff C, Domeyer M, Biesterfeld S, Galle PR, Junginger T, Moehler M. Expression of chemokine receptor CXCR4 in esophageal squamous cell and adenocarcinoma. BMC Cancer 2006 18;6:290.

24. Gros SJ, Graeff H, Drenckhan A, Kurschat N, Blessmann M, Rawnaq T, Izbicki JR. CXCR4/SDF1-alpha-mediated chemotaxis in an in vivo model of metastatic esophageal carcinoma. In Vivo 2012;26:711-8

25. Salazar N, Muñoz D, Kallifatidis G, Singh RK, Jordà M, Lokeshwar BL. The chemokine receptor CXCR7 interacts with EGFR to promote breast cancer cell proliferation. Mol Cancer 2014;13:198.

26. Velasco-Velázquez M, Jiao X, De La Fuente M, Pestell TG, Ertel A, Lisanti MP, Pestell RG. CCR5 antagonist blocks metastasis of basal breast cancer cells. Cancer Res 2012;72:3839-50. 